\title{
Application of Empirical Bathymetry Method on Sentinel 2A for Measuring Water Depth of Maninjau Lake
}

\author{
Wendri Arifin ${ }^{\mathrm{a}, *}$, Muhammad Hanif ${ }^{\mathrm{b}, *}$, Febriandi $^{\mathrm{a}}$, Triyatno ${ }^{\mathrm{c}}$, Ernieza Suhana Mokhtar ${ }^{\mathrm{d}}$, Eka Mutia ${ }^{\mathrm{e}}$ \\ a'Department of Remote Sensing Technology, Faculty Social Science, State University of Padang. Email: wendriarifin970@gmail.com \\ ${ }^{b}$ Department of Geography, Faculty of Social Science, State University of Padang. Email: hanif12mphy@gmail.com \\ 'Department of Environmental Science, School of Postgraduate Study, State University of Padang. Email: triyatno@ fis.unp.ac.id \\ ${ }^{\mathrm{d} D e p a r t m e n t}$ of Surveying Science and Geomatics, Faculty of Architecture Planning \& Surveying, Universiti Teknologi MARA. \\ Email: ernieza@uitm.edu.my \\ eDepartment of Civil Engineering, Faculty of Engineering, University Samudra, Aceh. Email: ekamutia@unsam.ac.id
}

\begin{abstract}
Lake Maninjau is a lake formed by volcanic activity. Many human activities occur in the catchment area, but also in exploited waters. This study aims to map the depth of the waters in Lake Maninjau and assess the effect of field sample distribution on the quality results of the image transformation. The data used are satellite imagery Sentinel 2A, results of the point survey. The analysis technique uses the normalized difference water index algorithm, sun glint, empirical bathymetry method, and linear regression. The result of the research has found that variations of distribution into the dispersion of the recording process of the depth of the object represented by the cell. The depth of the water from the results of this transformation refers to the measurement sample in the field survey. The maximum depth of the waters is in the range of $107 \mathrm{~m}$. Shallow waters are predominantly distributed in the northern region which is the out late of Lake Maninjau. The southern area forms a deep basin. The distribution of this sample is in the form of an empirical bathymetry map and the relationship between the results of field measurements and the transformation with a regression value of 0.769 , this indicates the consideration of total and distribution of survey sample is influence on the quality of the results of the transformation.
\end{abstract}

Keywords: Bathymetry; image transformations; water observation

\section{Introduction}

Lake is one of the natural landforms that is formed by natural processes and has very complex functions and systems. The lake ecosystem in Indonesia stores a wealth of germplasm, supplies by surface water, and use full for agriculture, community development, water sources, fisheries, agriculture, hydroelectric power, tourism, and others. Currently, many lakes in Indonesia have been degraded which is caused by population growth, land conversion, waste, chemical pollution, and erosion.

Lake Maninjau is the lake in Agam Regency, West Sumatra Province, Indonesia. Lake Maninjau is a volcanic lake located at an altitude of 461.50 meters above sea level. This is a caldera from a large volcanic eruption that scattered approximately $220-250 \mathrm{~km}^{3}$ of pyroclastic material. The other facts also reveal that the water quality of Lake Maninjau tends to decline in two decades, due to the increasing level of pollution due to domestic and agricultural waste disposal [1]. The environmental dynamics that occur in the catchment area of Lake Maninjau are the degradation of vegetation which largely decreases vegetation density as the impact

${ }^{*}$ Corresponding author. Tel.: +62-852-1050-4212

Address Jl. Hamka. Air Tawar Barat Kota Padang.

Padang, Indonesia, 25173 of land use around the catchment area [2]. Lake Maninjau exploited which is not followed by conservation efforts. The general problem faced is an increase in waste content which results in pollution and silting of these problems which in turn results in degradation of the lake environment and the death of fish in fishpond [3].

Mapping water body and bathymetric measurements were carried out by lowering the rope or cable using a weight to the seabed. This method is less efficient because it only measures the depth point in one point for a long time and has unsatisfactory accuracy. Advance technology of remote sensing has been used quite a lot for studies with the theme of limnology such as water quality monitoring, mapping of resource potentials, etc. Technology for measuring and mapping bathymetry is always evolving [4]. Remote sensing data to study the change of environment dynamic [5]. Furthermore, many remote sensing algorithms have been developed according to the user's need and develop geospatial modeling to assess environmental phenomena $[6,7]$. The technology uses an active sensor (LIDAR) is very useful in environmental observation, this technology is able to distinguish the condition of objects in the $x, y$ point information and height data in the form of $z$ points [8]. 


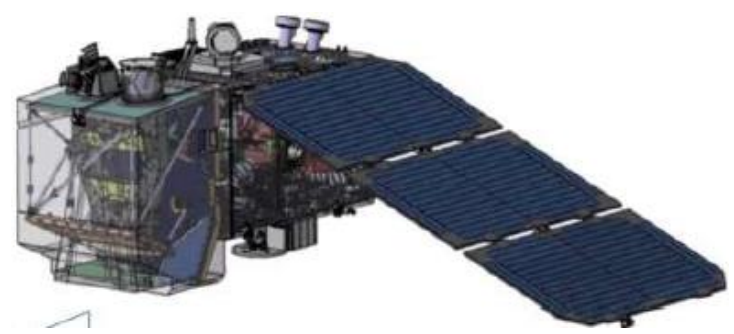

Figure 1. Satellite Sentinel 2 MSI [14]

Nevertheless, In this technology also provide sensitivity for water observation the method for bathymetric measurement [9]. The acoustic methods such as the use of echo-sounders and multi-beam provide accurate results however, both techniques in relatively high costs, large size, and limited coverage area. One solution for measuring and mapping bathymetry at an affordable cost and covering a wide area is to use remote sensing satellite technology $[10,11]$.

Today using a low-cost digital camera was use full to capture and observe the images of water bodies [12] Advance high-resolution imagery such as Quick-Bird is use full for investigation and study about hydrology process, water dynamic, rivers changes, and deposition [13]. QuickBird is also used to mapping bathymetry with the spatial $(\sim 2 \mathrm{~m})$ such as QuickBird and WorldView-2 can produce good bathymetry maps with a coefficient of determination above 0.80 and a root mean square error (RMSE) value below $0.6 \mathrm{~m}$ [14]. Unfortunately, these satellite images come at a high price. In contrast, the free use of satellite imagery with medium spatial resolution such as Landsat $(30 \mathrm{~m})$ can be used to produce medium resolution bathymetry maps with a determination coefficient of $0.6[14,15]$. Nevertheless, advance remote sensing in the Copernicus project such as sentinel 2a (Fig. 1) imagery and the arrival of new technologies for mapping bathymetry.

Sentinel-2 is a wide-swath, high-resolution, multispectral imaging mission, supporting Copernicus Land Monitoring studies, including the monitoring of vegetation, soil, and water cover, as well as observation of inland waterways and coastal areas. The SENTINEL-2 Multispectral Instrument (MSI) samples 13 spectral bands: four bands at 10 meters, six bands at 20 meters, and three bands at 60 meters spatial resolution. The acquired data, mission coverage, and high revisit frequency provide for the generation of geo-information at local, regional, national, and international scales. The data is designed to be modified and adapted by users interested in thematic areas such as spatial planning, agro-environmental monitoring, forest, and vegetation monitoring, land carbon, natural resource monitoring, global crop monitoring, and water monitoring [14]. With the availability of Sentinel satellite data with a higher resolution than medium resolution imagery for earth observation, sentinel satellites can be used for the exploration of water resources because they are supported by spectral sensitivity for water objects.

This research aims is to mapping the water's depth in the Lake Maninjau area of Agam Regency and assess the effect of field sample distribution on the quality of the result of image transformation. The research location is Lake Maninjau, West Sumatra Province. This lake is a volcanic lake or commonly known as the caldera of Tinau Mountain which is the result of ancient mountain eruptions. We decide to choose this location because it has a unique geological and natural landscape, and has complex environmental problems.

\section{Materials and Method}

\subsection{Data}

In this research, we use two data which we obtain from a website and ask the government. The data used is Sentinel 2A satellite imagery sourced from http://earthexplorere.usgs.gov this data free access and field sample output of echo-sounder which is obtained from River Basin Institute Indonesian government (BWS $\mathrm{V})$

\subsection{Analysis}

\section{a. Normalized Difference Water Index}

The index for separating the body of water and land is used to focus the research location on water areas. By applying the NDWI algorithm, it can discriminate between water and land where the band/image waves used are green-swri equation [16] as follows:

$$
N D W I=\frac{\text { Green }- \text { Swri }}{\text { Green }+ \text { Swri }}
$$

\section{b. Sun Glint Correction}

Sun glint is also commonly known as the Glinting, where sun glen is the sparkle on the surface of the water due to the reflection of the sparkling sunlight, the sparkling conditions of the sun on the surface of the water can cause errors when mapping the depth of the water body, then the equation is applied [17]:

$$
R_{i}^{\prime}=R_{i}-b i\left(R_{N I R}-\min _{N I R}\right)
$$

\section{c. Ratio Transform Algorithm (RTA)}

One of the algorithms that work in the empirical bathymetry method is the ratio transform algorithm, in which this transformation builds the results of the regression equation from the field measurement data with the logarithmic ratio of the two channels. The image used is usually a blue band or coastal band, this algorithm is able to extract it into a body of water up to a depth of $25 \mathrm{~m}$, provided that the water is in condition. This method is part of the Empirical Bathymetry method, which is the key in this study using field measurement data, in this study for field validation reference data used measurement data with eco-sounder measurement results by the BWS River Basin Institute equation [18]:

$$
Z=m 1 \frac{\ln (n R w(\lambda i))}{\ln (n R w(\lambda j))}-m 0
$$

where,

$$
\begin{array}{ll}
Z & : \text { water depth, } \\
m 1 & : \text { is (gain) to each depth ratio, } \\
m 0 & : \text { is (offset) } \\
R w & : \text { reflectance of water in the } K \mathrm{i} \text { or } K \mathrm{j} \text { band } \\
\lambda & : \text { spectral band }
\end{array}
$$


$n \quad$ : a constant value per area for the confidence of the positive logarithmic value of each case and the ratio which will refer to the linear regression response to the water depth response.

\section{Results and Discussion}

The bathymetric mapping process with the empirical bathymetry algorithm method will go through three main data processing stages, in which the sentinel image $2 \mathrm{a}$ is used and specifically is bands 2 and 3 . The selection of bands 2 and 3 are based on sentinel specifications and wave sensitivity in mapping water depth.

The first stage of the NDWI analysis is carried out in which this analysis aims to separate water and nonmarine objects. In this stage, the researcher successfully implemented the NDWI algorithm to highlight marine objects and discriminate non-waters objects to the made focus area in the bathymetric analysis process, then the results of the NDWI image transformation can be seen on the following map. The researchers succeeded in delineation the waters with an area of 9,950 ha. Furthermore, the bathymetry mapping process goes through the sun glint correction stage. In principle, sun glint correction aims to eliminate the reflection bias of sunlight reflected by the surface of the water to the atmosphere so that the original image will show the sparkle of the water surface so that it will cause an error in the analysis. So the application of sun glint correction, the sparkle of the water surface can be muted so that it is able to display the appearance of the actual water depth according to normal reflectance. At this stage, the sun glint correction is implemented to the two bands used. Figure 2 is a sun glint corrected image.

Figure 2 reveals the true color composite of the sentinel satellite image transformed by sunglint. The digital number of sentinel imagery that result of sun glint is at a high value of 4935 and low 0 . From the appearance of the image, the results of sunglint correction, the sun's glare bias are not visible to the sun. The comparison of the appearance of the image before sun glint correction and after the correction, which result of sun glint is very clear the difference in the appearance of the water surface. The image corrected by the sunglint which is free from light reflection by the water surface is suitable for the process of estimating the depth of the water because the quality of bias results of recording of objects by satellite has been eliminated in this process.

In this stage before using sentinel imagery, the most
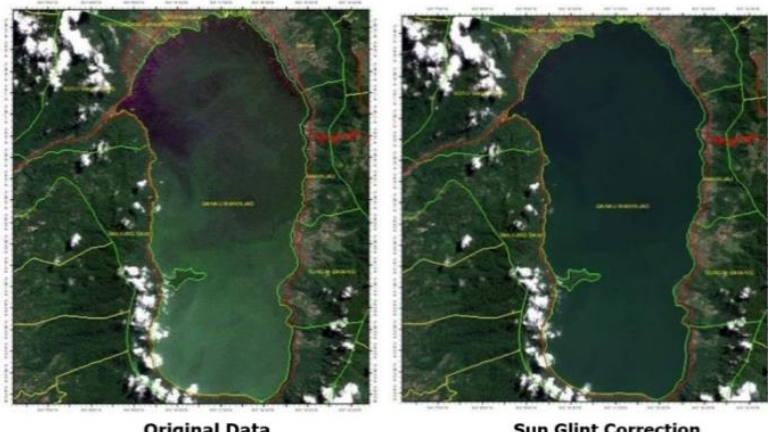

Figure 2. Comparison of images before and after sun glint correction important thing to look at is the clean appearance of the object (not covered by clouds), for consideration of the situation when recording objects after or before the rain is not really explained in the principle of the sun glint method because sun glint only tries to eliminate reflection bias sunlight by water objects.

The next stage is an analysis of empirical bathymetry which is the image that is processed output of sun glint correction. Then the important thing in the process is the transformation empirical bathymetry method which is the use of field data as a reference for transformation in analyzing image pixels. In this research, we used data from field surveys using echo-sounder data obtained from the Sumatra River Basin Institute (BWS V) therefore researchers did not have to re-measure to take primary data. The field survey data we use for the total sample is 1.220 points. This sample point will be a reference in the ratio transform algorithm analysis because in the extraction of sentinel image pixels into water depths, this algorithm must have reference sample data that is a reference for calculating the estimated water depth. To measuring water depth using the Empirical Bathymetry Method algorithm, several researchers also tried to carry out experiments but they did not use field primary data but used water depth points obtained from bathymetry maps, digital elevation mode DEM with coarser resolution as a reference point for water depth.

Figure 3 is the result of empirical bathymetry and interpolation survey data. The original result of empirical bathymetry it presenting depth. To facilitate interpretation of the depth of the waters, which is depth grouping is carried out in the form of interval classes. From Fig. 3, the researcher gives a symbol of dark blue to bright blue, where the dark blue color indicates that the location is deep water, while bright blue is shallow water. In this study, we also present the results of interpolation of waters using it to compare the waters from the survey data and the results of the transformation of satellite images. These two images show the comparison of the depth of the waters measured in the field with the results of the digital image transformation. The map information is not very informative so it is necessary to classify the depth of the waters on an interval scale.

Figure 3 is a map image of the results for the depth waters. From this figure, it can be seen that there is a difference in the depth of the waters between the interpolation of field measurements and the results of bathymetric analysis using the image algorithm. This figure compares contras difference on object shallow water at a depth of 0 - 37 meters, wherein the result of the survey the area around of the edge of the lake shows a faded color which is the appearance of shallow water. However the results of analysis image sentinel 2A, it can be seen that the shallow water area of $0-37$ meters is only clearly scattered on the left and right of the lake. In the deepwater interpolation model from 91 - 107 meters, it is centered on the spot in the middle of the lake caldera, while in the 2A sentinel analysis model the deep waters of the lake Maninjau are more spread out in the caldera part of the lake. 

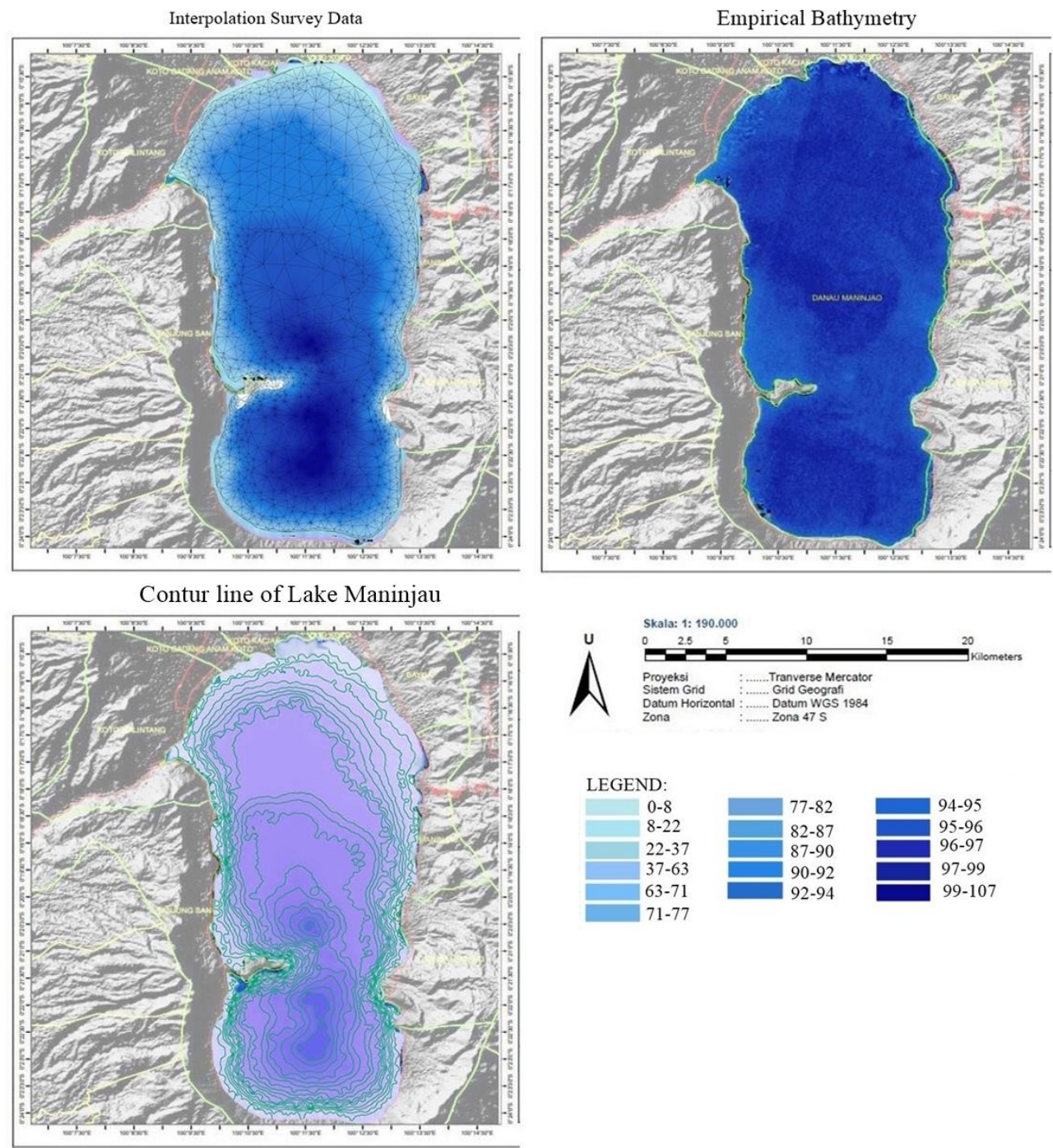

Figure 3. Bathymetry of Lake Maninjau

The difference between the results of field measurements and the results of sentinel image analysis is due to the process of data collection. satellites record objects based on the response of light reflected by objects that reflect the depth of the water, this shows the depth of the water, and this sentinel analysis model is very dependent on field data. This sentinel satellite is not a satellite with active sensors such as LAS LiDAR, the extraction of this water depth can be done without using field data, but it must have water depth information in a location, for example from DEM digital elevation mode data, it is necessary to pay attention to the difference in data that is a reference for calculations in This empirical bathymetry algorithm will affect the quality of the results.

From Fig. 3 The results of this study for the distribution of water depths using Sentinel have differences in the location of deep waters with the results of the Eco sounder measurement. This difference does not only occur in variations in the distribution of deep waters. This difference has been widely discussed by previous researchers because sentinels are very effective for mapping shallow water depths. The limitation of this sentinel is because the sentinel is a passive sensor satellite that only records object information from the reflection of the object with the help of sunlight, the sentinel does not have the technology to emit its own waves, so this limitation makes a difference in the bias of the analysis results.

The process of analyzing the relationship between survey data and the results of the empirical transformation of the bathymetry is important because the results of the literature study state that this algorithm is very efficient for measuring water depths up to a depth of $25 \mathrm{~m}$, whereas from the transformation model carried out, the researchers succeeded in finding the maximum depth waters of the Lake Maninjau at $107 \mathrm{~m}$.

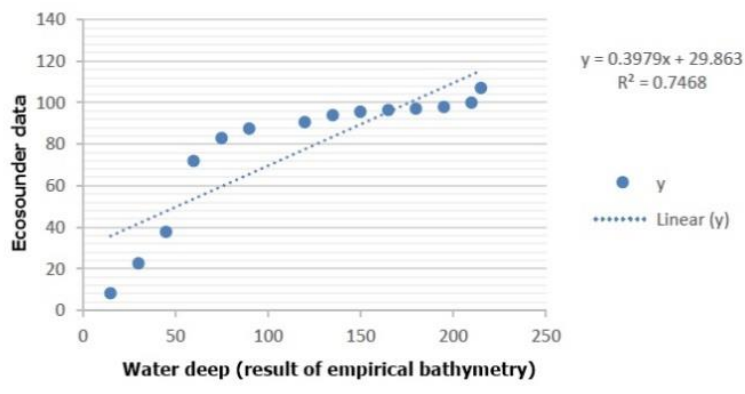

Figure 4. Relationship field data and result of empirical bathymetry 
The process of analyzing the relationship between these two data is by making the field data from the ecosounder measurement as the $x$ variable and the result of the transformation of the empirical bathymetry as the $y$ variable (Fig. 4). Researchers take the same pixel information as the coordinates of the field measurements. From the analysis of the relationship between the two data, the researcher managed to find the regression coefficient value with a value of 0.7468 . Based on the research, it was found the depth waters of Lake Maninjau by going through several stages of data analysis. The use of NDWI transformations is proven to be very efficient in delineating the watershed area because this transformation is very sensitive in discriminating against non-water objects. The results of this study are very relevant to the NDWI transformation concept described by $\mathrm{Xu}$ [17] which the use of green and swirling waves in NDWI transformation is able to separate water and non-water objects. Furthermore, the results of this study also reveal the comparison on image information which appearance of the object from the image recording result of sun glint correction and the original image. It was found that sun glint correction was able to eliminate the bias of light on the water. Information on water imagery as research objects looks more normal on the true color image. Based on the statement of Hedley [18] the application of sun glint correction is very effective in removing the glint of sunlight on the surface of the exposure in the recorded image. So the findings in the results of this study are very relevant to the statements made by previous researchers regarding the use of the sun glint correction method in reducing light bias on the water surface.

The depth of the waters was successfully mapped in this case where the maximum depth was obtained in the range of $107 \mathrm{~m}$, the depth of this circulation was from the extraction of data bands 2 and 3 which was further analyzed with field data, the depth distribution of this circulation has two main spots scattered in the northern region. and south. Stumpf [19] who have proposed an empirical transformation model of bathymetry in their journals has also succeeded in discriminating water depth objects. So the results of this study are proven to have successfully implemented the same algorithm at locations with different geographical characteristics.

The linear regression test has succeeded in proving the performance between the field data and the results of the transformation of the empirical bathymetry method with the regression coefficient value obtained that is 0.769. This proves that the two variables have a strong relationship. Nevertheless, a linear regression curve also represents the extent of the relationship between the two variables where the variable $\mathrm{x}$ and variable $\mathrm{y}$ are not too far away, so we can understand that the empirical transformation of this method can be implemented in the region of the broadcast with different geographical characteristics. Field measurement data and water objects that are mapped are in clear conditions, meaning that the water area does not have a solid sediment suspension which causes errors in the water depth mapping.

\section{Conclusion}

In the process of mapping bathymetry, the empirical bathymetry algorithm method was used. Results of the shallow waters are at intervals of 0 to 8 meters, moderate waters are 77 to 92 meters, deep waters are 93 to 96 meters and very deep waters are 97 to 107 meters were taken. The linear regression test relationship has succeeded in proving the performance between field data and the results of the transformation of the empirical bathymetry method with the regression coefficient value obtained is 0.769 where the relationship is very strong this indicates the consideration of total and distribution of survey sample is influence on the quality of the results of the transformation.

\section{Acknowledgment}

The authors wish to thank the government for support and we also express our gratitude to all those who have helped with the administration process, as well as those who helped us in the field.

\section{References}

[1] Asnil, et al. 2013. Analisis Kebijakan Pemanfaatan Sumberdaya Danau Yang Berkelanjutan (Studi Kasus Danau Maninjau Sumatera Barat). Jurnal Pengelolaan Sumberdaya Alam dan Lingkungan Vol. 3 No. 1 (Juli 2013): 1-9. ISSN 2086-4639. https://journal.ipb.ac.id/index.php/jpsl/article/view/10629

[2] Hanif M .2016. Studi Perubahan Kerapatan Vegetasi Catchment Area Danau Maninjau dengan Teknologi Penginderaan Jauh dan Sistem Informasi Geografi.(Skripsi). Padang: FIS UNP. https://scholar.google.co.id/scholar?oi=bibs\&cluster=85617898265 $67255196 \&$ btnI $=1 \&$ hl $=\mathrm{id}$

[3] Lembaga Ilmu Pengetahuan Indonesia. 2010. Kajian Hidroklimatologi Sebagai Dasar Pengembangan Sistem Peringatan Dini Bencana Kematian Massal Ikan 01 Danau Maninjau Sumbar. Laporan Akhir Program Insentif Peneliti Dan Pereka Vasa LIPI. https://www.scribd.com/doc/184080130/morfometri-pdf

[4] Wahyuningrum, P.I. 2007. Pengembangan Algoritma untuk Estimasi Kedalaman Perairan Dangkal Menggunakan Data LANDSAT-7 ETM (Studi Kasus Perairan Gugus Pulau Pari Kepulauan Seribu, Jakarta) [Disertasi]. Sekolah Pascasarjana. IPB, Bogor. https://repository.ipb.ac.id/handle/123456789/9870

[5] Hanif M, et. All. 2019. Multi Spectral Satellite Data to Investigate Land Expansion and Related Micro Climate Change as Threats to the Environment IOP Conf. Series: Earth and Environmental Science $\quad \mathbf{3 0 3}$ (2019) 012030. doi:10.1088/17551315/303/1/012030.https://iopscience.iop.org/article/10.1088/1755$1315 / 303 / 1 / 012030$

[6] Cambell, J. B and R.H. Wynee. 2011. Introduction to Remote Sensing, Fifth Edition. New York: Guildford Press. ISBN 978-160918-176-5.

https://www.researchgate.net/publication/255172213_Introduction _to_Remote_Sensing

[7] Hidayat R A. 2020. Spatial Modeling of The Threat of Damage to The Peatland Ecosystem In The Mainland of Bengkalis Regency, Riau Province. Journal Social Polites. Vol 20. Special Issue. No 2. doi: http://ejournal.uki.ac.id/index.php/sp/article/view/2249

[8] Hanif M and Nofrizal A Y (2017) Investigation Natural Forest Ecosystem Use High Resolution and Lidar Data. Journal Environment and Earth Science IIESTE. Vol 9. https://iiste.org/Journals/index.php/JEES/article/view/39222

[9] Halls Joanne and Coastin Kaitlyn. 2016. Submerged and Emergent Land Cover and Bathymetric Mapping of Estuarine Habitats Using WorldView-2 and LiDAR Imagery. Journal Remote Sensing MDPI. Vol 8. Issue 9. DOI. 10.3390/rs8090718. https://www.mdpi.com/2072-4292/8/9/718

[10] Arief M. 2012. Pendekatan Baru Pemetaan Bathymetryc Menggunakan Data Jauh SPOT, Studi Kasus Teluk Parigi dan Teluk Popoh. Jurnal Teknologi Dirgantara. 10 (1) : 71-72. http://jurnal.lapan.go.id/index.php/jurnal_tekgan/article/view/1727 
[11] Horta Joa, etal. 2014. Can recreational Echosounder-Chartplotter systems be used to perform accurate nearshore bathymetric surveys? Journal Ocean Dynamics Springer. 64 (11):1555-1567. DOI: 10.1007/s10236-014-0773-y. http://www.cima.ualg.pt/cimaualg/index.php/pt/153research/publicacoes?limit $=6 \&$ start $=6$

[12] Mokhtar Suhana Ernieza, Mohd Wan Naim Mohd Wan 2011. Utilizing Low-Cost Digital Cameras And Gis Technique For Mapping Water Quality Of Inland Water Bodies. ISG \& ISPRS 2011, Sept. 27-29,- Shah Alam, MALAYSIA https://www.researchgate.net/publication/268746076_UTILIZING LOW-

COST_DIGITAL_CAMERAS_AND_GIS_TECHNIQUE_FOR MAPPING_WATER_QUALITY OF_INLAND_WATER_BODI ES

[13] Hanif M, et al. 2020. The High Resolution Imagery to Mapping the Dynamics of River Flow Patterns, and Deposition on Fluvial Landform of Sianok Canyon. Journal of Remote Sensing GIS and Technology. Volume-6, Issue-1 (January-April. http://doi.org/10.5281/zenodo.3700308

http://matjournals.in/index.php/JORSGT/article/view/4819

[14] Correa Liceaga M. A. -And -Avila Euan J. I. 2002. Assessment of coral reef bathymetric mapping using visible Landsat Thematic Mapper data. International Journal Remote Sensing Vol 23. No 1. 3-14. Taylor and Francis Group. ISSN 0143-1 161. DOI: 10.1080 0143 https://www.tandfonline.com/doi/abs/10.1080/0143116001000857

[15] Kiat, Ng Chi. 2004. The kings of the rivers Mahseer in Malayan and the region. Selangor: Inter Sea Fishery. https://www.worldcat.org/title/kings-of-the-rivers-mahseer-inmalaysia-and-the-region/oclc/63126334

[16] European Space Agency (2015) Sentinel 2 User Hand Book. Issue 1 Rev 2. European Commission. https://sentinel.esa.int/web/sentinel/user-guides/sentinel-2$\mathrm{msi} /$ document-library/-

/asset_publisher/Wk0TKajiISaR/content/sentinel-2-user-handbook

[17] Xu, H. 2006. Modofication of Normalized Diffrerence Water Index (NDI) to enchance Open Water Feautures in Remote Sensed Imagery. International Journa of Remote Sensing. Vol 27 (14). Pp. 3025-3033.

https://www.tandfonline.com/doi/abs/10.1080/0143116060058917 9

[18] Hadley. .D., etal. 2005. Technical note. Simple and robust removal of sun glint for mapping shallow water benthos. International Journal of Remote Sensing. Vol 26 (10) pp.2107-2112. https://www.tandfonline.com/doi/abs/10.1080/0143116050003408 6

[19] Stumpf. R.P et.al. 2003. Determination of Water Depth With high resolution satellite imagery over variable bottom types. Limnology and Oceanography. Vol 48 (1/2) pp. 547-556 https://aslopubs.onlinelibrary.wiley.com/doi/abs/10.4319/1o.2003.4 8.1_part_2.0547 